Yanzhen ZHU' ${ }^{1}$, Yanjun ZENG ${ }^{2}$, Caigu HE${ }^{1}$, Shu JIANG ${ }^{1}$, Linying ZHOU ${ }^{3}$, Yumei $\mathrm{HUANG}^{1}$, Changhui QIANG ${ }^{1}$, Yiyan JIANG ${ }^{1}$

\title{
EFFECTS OF A CARDIOTONIC MEDICINE DANSHEN PILLS, ON COGNITIVE ABILITY AND EXPRESSION OF PSD-95 IN A VASCULAR DEMENTIA RAT MODEL
}

\begin{abstract}
Received June 10, 2014
A widely used Chinese cardiotonic proprietary medicine, compound Danshen dripping pills (CDDP, Fufang Danshen Diwan) has also begun to be used for treatment of vascular dementia (VaD). We tried to explore the mechanism of CDDP action in this case. A VaD experimental model was built in rats by bilateral ligation of the common carotid arteries. The cognitive ability of experimental animals was evaluated in the Morris water maze test. Synaptic ultrastructural changes in the hippocampus were detected by transmission electron microscopy; expression of PSD-95 mRNA in the hippocampus was examined using hybridization in situ. The latter index (mRNA expression) in the VaD group was significantly lower than those in the CDDP and shamoperated groups $(P<0.05)$. CDDP treatment considerably improved disturbed ultrastructural synaptic characteristics in the hippocampus of $\mathrm{VaD}$ rats. The mean escape latency in the Morris water maze test was significantly shorter in CDDP-treated VaD rats, compared with that those of the VD group $(P<0.05)$. In the CDDP group compared to the VaD one, escape strategies improved from edge and random searches to more linear swim pathway $(P<0.05)$. Thus, decreasing expression of PSD-95 plays an important role in the pathogenesis of VaD. CDDP treatment improves the learning and memory ability of $\mathrm{VaD}$ rats by improving neural synaptic ultrastructural characteristics and increasing expression of PSD-95 mRNA in the hippocampus.
\end{abstract}

Keywords: compound Danshen dripping pill, hippocampus, Morris water maze, PSD-95, synapsis, vascular dementia.

\section{INTRODUCTION}

Vascular dementia (VaD) is a clinical syndrome of cognitive decline caused by ischemic, hemorrhagic, or oligemic injury to the brain as a consequence of cardiovascular and/or cerebrovascular diseases [1]. In the United States and Europe, it accounts for 10-20\% of dementia cases [2,3] and greatly impacts on the patients' life quality and national economies. Within an aging population, $\mathrm{VaD}$ will become the more prevalent disease in the future. Officially approved definitive medical or surgical treatments for vascular dementia still remain limited [4]; thus, the development of effective treatments for $\mathrm{VaD}$ would be of great importance.

Compound Danshen dripping pills (CDDP; Fufang Danshen Diwan in Chinese) is a well-known Chinese

\footnotetext{
1 Department of Integrative Medicine, Fujian University of Traditional Chinese Medicine, Fujian, China.

${ }^{2}$ Biomechanical and Medical Information Institute, Beijing University of Technology, Beijing, China.

${ }^{3}$ Department of Electron Microscopy, Fujian Medical University, Fujian, China.

Correspondence should be addressed to Yanjun Zeng

(e-mail: yjzeng@bjut.edu.cn).
}

proprietary medicinal formula. It is exclusively broadly used in China and some other countries for treating vascular diseases, including cardiovascular and cerebrovascular ones $[5,6]$. Clinically, CDDP have been shown to produce beneficial effects on $\mathrm{VaD}$ and stroke patients in China. Our previous experiments showed that CDDP noticeably improved the learning and memory ability of $\mathrm{VaD}$ rats by inhibiting expression of Bax and caspase- 3 in the hippocampus. These evidences suggest a significant positive effect of CDDP on VaD. However, the molecular mechanisms of such effect remained poorly known, and this topic is worth further study.

There is a widespread agreement that memory can be encoded by activity-dependent changes in the transmission strength of synapses. Considerable data showed that synaptic ultrastructural and functional impairment contributes to VaD [7]. One of important postsynaptic density-related proteins is PSD-95. It plays a central role in the regulation of synaptic functions, and it is also significant for the learning and memory ability [8]. At the same time, the role of PSD95 in the pathogenesis of $\mathrm{VaD}$ remained unclear. The 
aim of this our study was to evaluate the role of PSD95 in the VaD pathogenesis and to estimate the effect of CDDP on the expression of PSD-95 in VaD rats.

\section{METHODS}

Animal Selection. A total of 40 healthy female Sprague-Dawley rats, belonging to a specific pathogen-free grade, aged 12 months, and weighing $432 \pm 30 \mathrm{~g}$, were provided by the Research Center of Laboratory Animals (Academy of Military Medical Sciences, China, permission No. SCXK (Jun) 2007004). Animals were maintained under conditions of the controlled temperature $\left(22 \pm 2{ }^{\circ} \mathrm{C}\right)$, humidity $(50$ $70 \%$ ), and illumination (12-h light-dark cycle with lights on at 7:00) with free access to food and water. Thirty-seven rats with good learning and memory abilities were selected according to the Morris water maze criteria, while three animals were eliminated.

Preparation and Grouping of Animal Models. Nine rats were selected to the sham-operated (sham) group, and 28 rats were used for VaD modeling, which was induced by bilateral occlusion of the common carotid arteries [9]. Under anesthesia (choralhydrate $3 \mathrm{mg} / \mathrm{kg}$ ), rats were fixed in a supine position, and a midline incision of the cervical skin was made to expose bilaterally the carotid arteries; the latter were ligated with double silk sutures; then the rats were regularly fed and observed. After induction of the VaD model, the surviving rats were randomly assigned into the VD $(n=10)$ and CDDP-treated $(n=10)$ groups. The sham group received the same surgical procedures, but the common carotid arteries were not occluded.

CDDP Used to Treat the VaD Rats. Ten days after surgery, CDDP (Tasly Pharmaceutical Corporation, Tanjian, China) was dissolved in normal saline and administered to rats of the CDDP group. Each rat this group was given CDDP at dose of $75 \mathrm{mg} / \mathrm{kg}$ by gastrogavage once a day for 20 days. The rats of the sham and $\mathrm{VaD}$ groups were reared under the same conditions, without any treatment.

Morris Water Maze Test. Two months after surgery, the behavioral Morris water maze test was conducted. A circular tank $(150 \mathrm{~cm}$ diameter, $50 \mathrm{~cm}$ deep) was filled with $17-\mathrm{cm}$ deep water of $22-26^{\circ} \mathrm{C}$. Four entering points were marked on the wall of the pool, and the pool was divided into four quadrants. The platform (12.5 cm diameter, $15 \mathrm{~cm}$ high) was placed in the third quadrant; it was submerged $2 \mathrm{~cm}$ below the water surface [9].
The Navigation Test for Evaluation of the Learning and Memory Ability. The test lasted for 5 days with four trials per day. Each trial began by releasing the rat into water, with its muzzle toward the pool wall at one of the four placement points. The time to find the platform within a 2-min limit was recorded. If the rat failed to find the platform within $2 \mathrm{~min}$, the experimenter moved the animal to the platform, where it remained for $10 \mathrm{sec}$, and the escape latency was measured within 2-min-long interval.

Spatial Memory Ability of Rats Analyzed by the Spatial Probe Test. The platform was removed from the pool, and rats were allowed to search for the platform within $120 \mathrm{sec}$. Swim paths were recorded to determine search strategies; this included the search along an edge swim path (edge type), that along a random swim path (random type), a trend toward a straight swim path (trend type), and a linear swim path (line type).

Electron Microscopy of the Hippocampus. After cervical dislocation, the animals were sacrificed, the rat brain was quickly taken off, and the hippocampus was isolated on an ice plate. Hippocampal tissues were kept in a fixative containing $3 \%$ glutaraldehyde and $1.5 \%$ paraformaldehyde (in $0.1 \mathrm{M} \mathrm{PBS}, \mathrm{pH} 7.4$ ). A tissue block (about $1 \mathrm{~mm} \times 1 \mathrm{~mm} \times 3 \mathrm{~mm}$ ) of the $C A 1$ region was taken from the hippocampus and fixed in the same fixative for $24 \mathrm{~h}$. Then it was immersed in the fixative including $1 \%$ osmic acid and $1.5 \%$ potassium ferrocyanate for $1.5 \mathrm{~h}$. The tissue was stained overnight with uranyl acetate, dehydrated with ethanol and acetone, and embedded in Epon 618. One- $\mu$ m-thick sections were taken from each block and stained with uranyl acetate and lead citrate. Ultrathin sections were cut, placed on uncoated or coated grids, and observed with a Philips - EM208 electron microscope.

Preparation of Paraffin Sections. Under anesthesia with choral hydrate, the rat brain was taken off, and hippocampal tissues were isolated on an ice plate, postfixed in $10 \%$ neutral formalin for $12 \mathrm{~h}$, dehydrated through an ethanol series, embedded in paraffin, and serially sectioned (6- $\mu \mathrm{m}$ thick coronal sections).

In Situ Hybridization Used to Evaluate Hippocampal PSD95 mRNA Expression. Hybridization in situ was performed according to the instruction for a kit of hybridization in situ given by the producer (Boshide, China). Briefly, after deparaffinage and rehydration, the brain section was kept in $3 \% \mathrm{H}_{2} \mathrm{O}_{2}$, at room temperature for $5-10 \mathrm{~min}$, to inactivate the endogenous enzyme, and then digested with peptase for $2 \mathrm{~min}$. After processing with $20 \mu 1$ prehybridization solution, each section was processed in $20 \mu 1$ 
hybridization solution overnight at $40^{\circ} \mathrm{C}$, in biotinylated mouse anti-digoxin at $37^{\circ} \mathrm{C}$ for $1 \mathrm{~h}$, and in biotinylated peroxidase at $37^{\circ} \mathrm{C}$ for $20 \mathrm{~min}$. With horseradish peroxidase catalysis, 3,3N-diaminobenzidine tertrahydrochloride (DAB) was used to color a masculine position of the section. PSD-95 mRNApositive cells and nerve cells in the hippocampal CAI region were observed using a Nikon 55i microscope. The percentage of PSD-95 mRNA-positive cells in each hippocampal $C A 1$ section was calculated.

Statistical Analysis. Data were statistically treated by the first coauthor using SPSS 13.0 software. Data for the escape latency and results of hybridization in situ were analyzed with one-way ANOVA and the LSD post hoc test. The $\chi^{2}$ test and partition $\chi^{2}$ tests were used for spatial probe analysis.

\section{RESULTS}

Learning and Memory Ability of VaD Rats Treated with CDDP. The navigation test in the Morris water maze was used to evaluate the learning and memory ability of the examined rats. The mean escape latencies in the sham, $\mathrm{VaD}$, and CDDP groups were $10.72 \pm$ $2.40,43.00 \pm 5.38$ and $19.71 \pm 4.28 \mathrm{sec}$, respectively. The LSD test showed that the average latency in the VaD group was significantly longer than those in the sham and CDDP groups $(P<0.05)$. The $\chi^{2}$ test showed that escape strategies in the spatial probe test

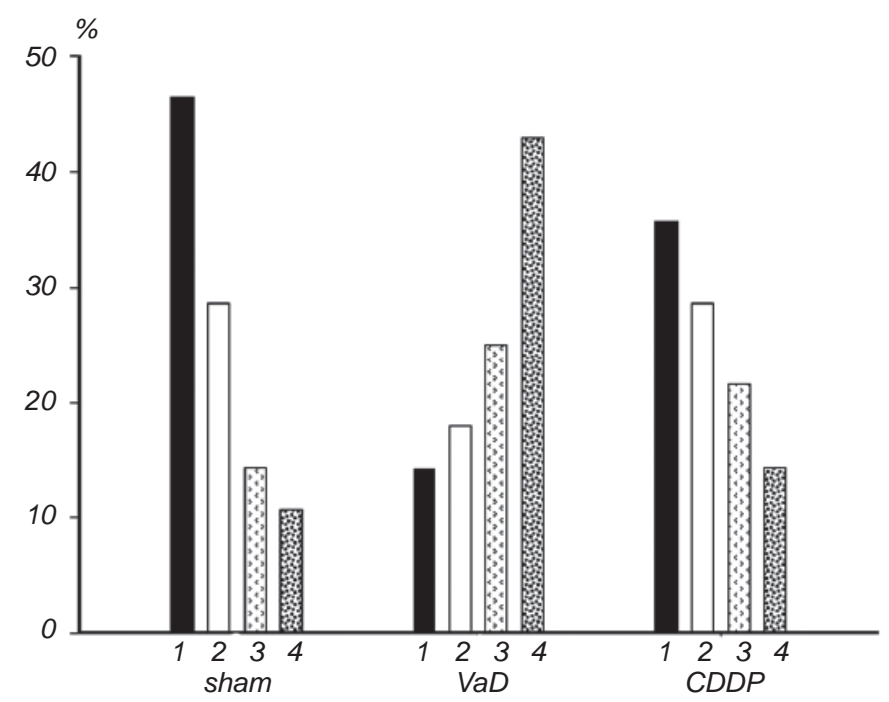

F i g. 1. Proportions, \%, of using different spatial strategies (1-4) in the water maze test by rats of the experimental groups. 1-4) Line type, 2) trend type, 3 ) random type, and 4) edge type.

Р и с. 1. Нормована частота (\%) використання різних просторових стратегій у тесті водного лабіринту щурами експериментальних груп. showed significant differences among the three groups $(P<0.05)$, and partition by the $\chi^{2}$ test demonstrated noticeable differences of escape strategies between the VaD group and CDDP groups. Escape strategies were clearly improved from edge and random searches to more linear swim pathways in the CDDP group, compared to those in the VaD group (Fig. 1).
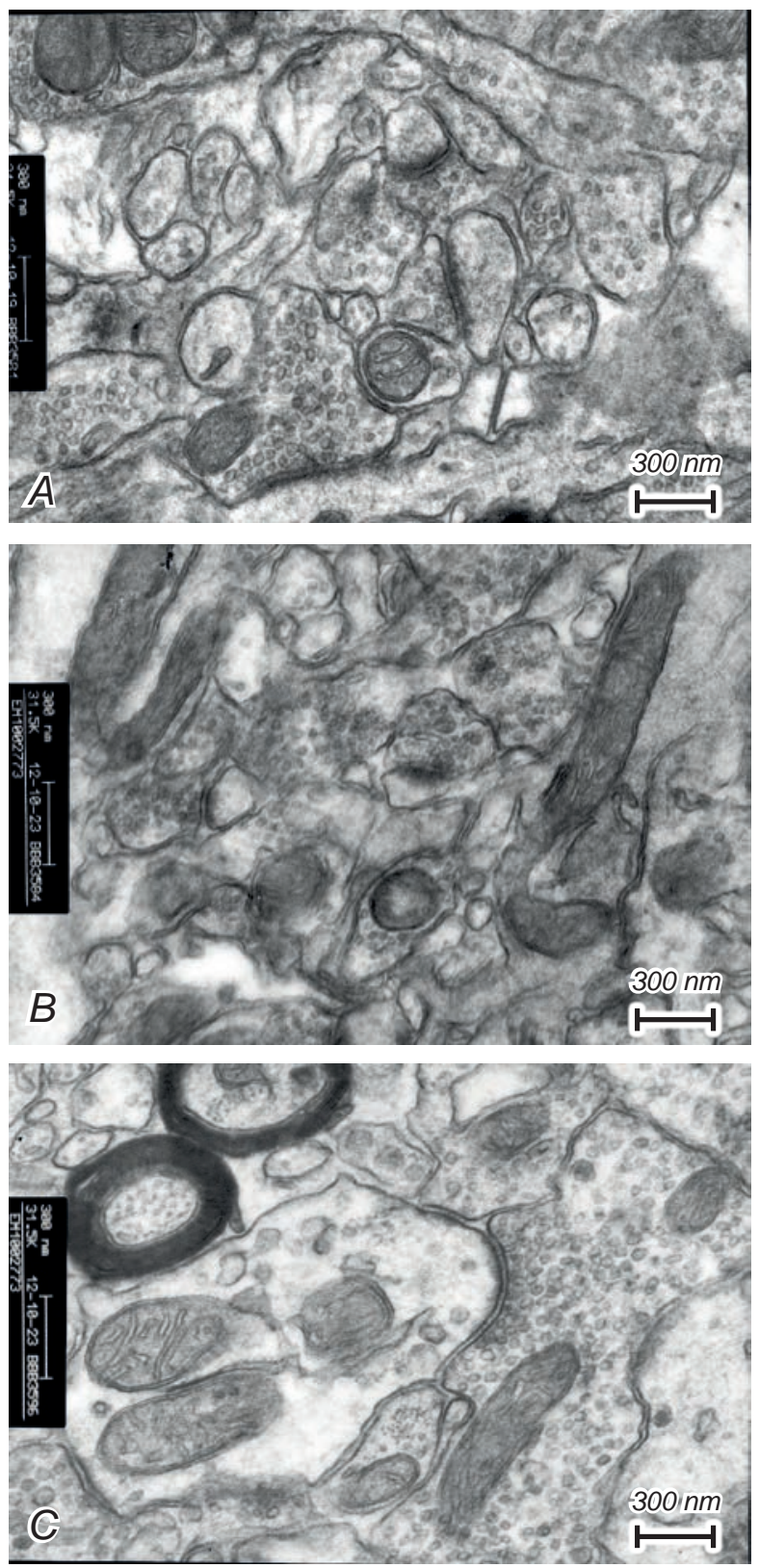

F i g. 2. Representative examples of ultrastructural characteristics of synaptic structures in the hippocampus of rats of the sham, $\mathrm{VaD}$, and CDDP groups ( $A-C$, respectively).

Р и с. 2. Типові приклади ультраструктури синаптичних утворень у гіпокампі щурів груп контролю, $\mathrm{VaD}$ та $\mathrm{CDDP}(A-C$ відповідно). 


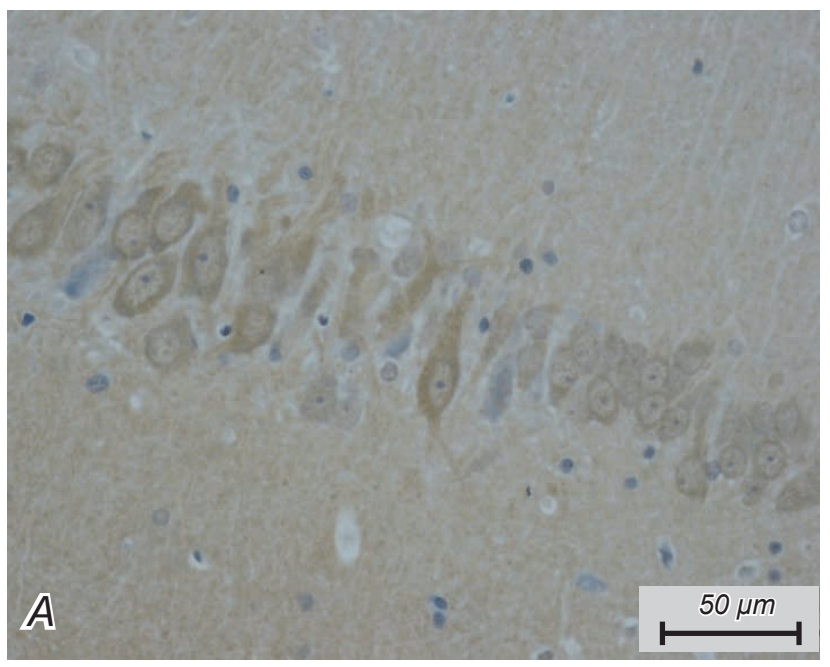

Synaptic Ultrastructural Patterns in the Experimental Groups. In rats of the sham group; the presynaptic membranes, postsynaptic membranes, and synaptic cleft were clear. There were many synaptic vesicles in the presynaptic components, and prominent postsynaptic densities (PSDs) were observed in the postsynaptic components.

In the VaD group; the presynaptic and postsynaptic membranes got unclear. Synapses had noticeably fewer synaptic vesicles in their presynaptic components and thinner postsynaptic densities in the postsynaptic components. Clear swelling appeared in some presynaptic and postsynaptic components.

As was found in the CDDP group, the treatment with this mean clearly improved synaptic ultrastructural patterns in the hippocampus. Compared with the
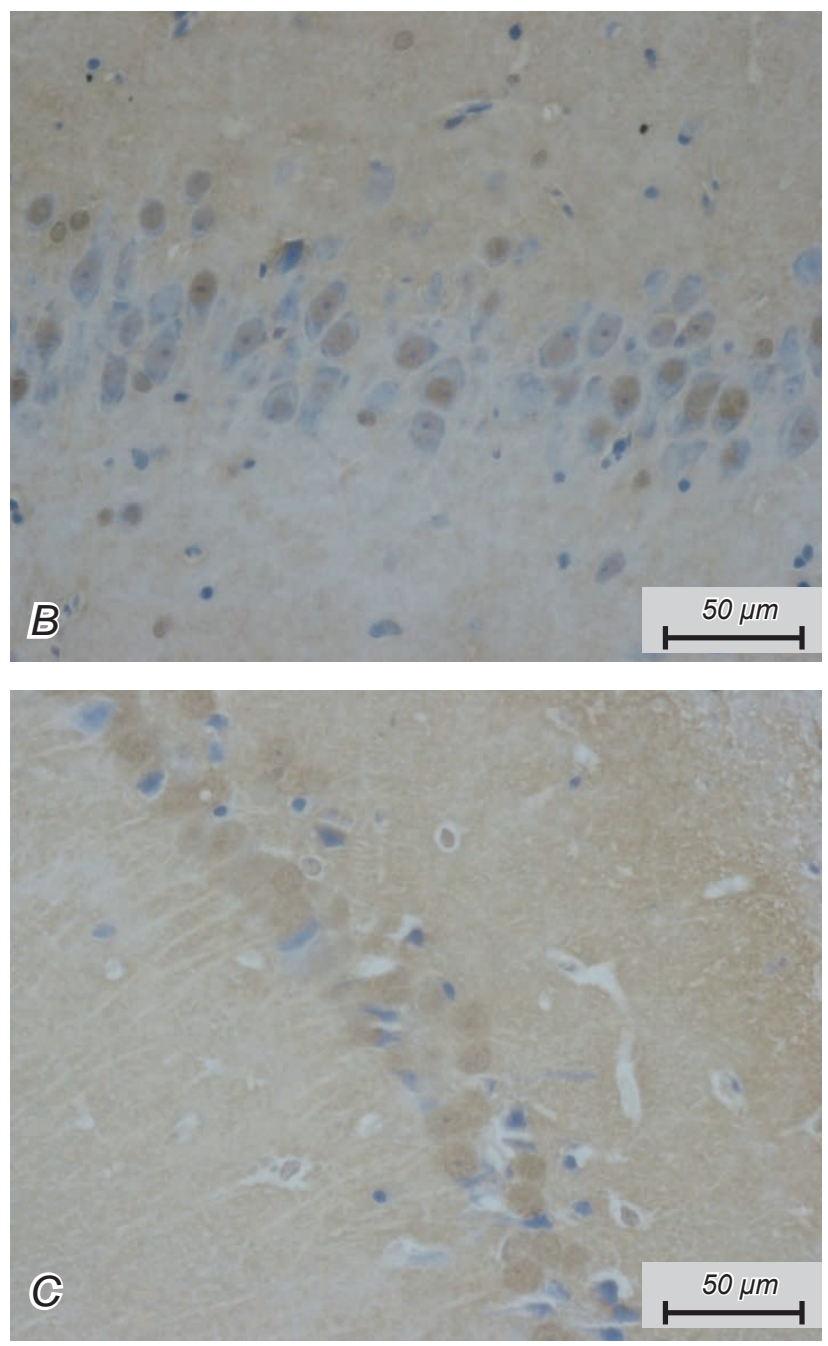
VaD group, the presynaptic and postsynaptic surfaces got clearer, much more synaptic vesicles were observed, and the postsynaptic densities became thicker. Swelling in the presynaptic and postsynaptic components alleviated.

Expression of PSD 95 mRNA Examined by Hybridization in Situ. PSD-95 is predominantly localized within synapses, and it was shown to play an important role in synaptic plasticity. Hybridization in situ was conducted to assess the role of PSD-95 in CDDP treating of VaD. PSD-95 mRNA-positive loci

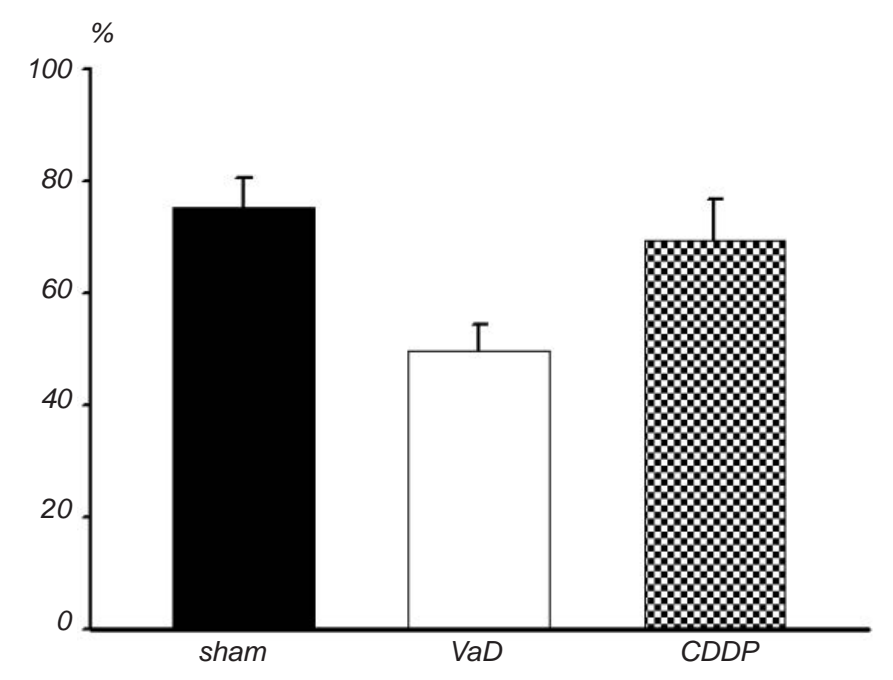

F i g. 3. PSD-95 mRNA-positive cells (hybridization in situ) in rats of the sham, VaD, and CDDP groups (A-C, respectively).

P и с. 3. PSD-95 мРНК-позитивні клітини (виєвлення за допомогою гибридізації in situ) у щурів трьох груп $(A-C)$. 
appeared in the cytoplasm and nuclei of hippocampal CA1 nerve cells (Fig. 3). Compared with that in the sham group, expression of PSD 95 mRNA was significantly lower in the hippocampus of VaDgroup rats $(P<0.05)$. CDDP treatment considerably increased expression of PSD $95 \mathrm{mRNA}$, as compared to that in $\mathrm{VaD}$ rats $(P<0.05)$ (Figs. 3 and 4$)$.

\section{DISCUSSION}

The Morris water maze test gas been widely used to evaluate the learning and memory ability (especially spatial memorization) in rats [10]. The mean escape latency refers to the average time for rats to initiate finding of the platform, which reflects the level of learning and memory ability of the animals. Search strategy in the spatial probe test refers to the path of rats to swim to the safe space (the platform) according to the surrounding environment, and the respective indices reflect the space memory ability of rats. This mainly includes the edge, random, tend, and straight types. Navigation test results showed that the average escape latency in the $\mathrm{VaD}$ group was significantly longer than that in normal rats, and CDDP treatment noticeably decreased the average escape latency in $\mathrm{VaD}$ rats. The spatial probe test results proved that the proportions of edge-type and random-type strategies were noticeably greater in the $\mathrm{VaD}$ group compared with those in the sham group. This was indicative of the poor space memory ability in the VaD group [11, 12]. It was obvious that CDDP treatment improved the search strategies of $\mathrm{VaD}$ rats. A complex of these data indicated that there is a significant positive effect of CDDP on the cognitive function in the above rats.

The PSD is a specialized cytoskeletal structure lying beneath the postsynaptic membrane. It is involved in the regulation of synaptic functions and modulation of postsynaptic responses [13]. PSD-95 is the best-characterized protein member of the PSD family and an effective postsynaptic biomarker. It enhances postsynaptic clustering and plays important roles in integration of postsynaptic signals [14]. In ischemic rats, PSD-95 expression in the hippocampus was significantly lower compared with that in shamoperated animals $[15,16]$. This fact suggests that down-regulation of PSD-95 is an important factor in ischemic encephalopathy. Our study showed that ultrastructural impairment of the synapses including thinning of the PSD was obvious in the VaD group, and hippocampal PSD-95 mRNA expression significantly decreased in this group. Such results suggest that hippocampal ischemia induced by bilateral switchingoff of the common carotid arteries led to obvious reduction of the postsynaptic density thickness and a decrease in the expression of PSD-95 mRNA. It also affected the efficiency of synaptic transmission. These events, naturally, resulted in a learning and memory deficits.

CDDP is a classical and widespread prescription for the treatment of cardiovascular diseases. Recently, it began also to be used for that of cerebrovascular disease [17]. Clinically, CDDP exerts significant effects in treating $\mathrm{VaD}$ by slowing-down progression of this pathology. The reason may be related to the CDDP function of promoting blood circulation and removing blood stasis. The main constituents of CDDP are radix salviae miltiorrhizae, radix notoginseng, and borneolum syntheticum. Radix salviae miltiorrhizae is the most important component of this medicine. It exerts multifacial positive effects (decreasing constriction of the blood vessels, improving circulation, relieving blood stasis, and changing the blood viscidity). In ischemia rats, active constituents of radix salviae miltiorrhizae provide cerebroprotection by reducing apotposis and inhibiting NOS gene expression [18, 19]. Radix notoginseng has the following effects: decreasing platelet superficial activation, inhibiting platelet adhesion and aggregation, preventing thrombosis, and improving microcirculation [20]. Borneolum increases the permeability of the blood-brain barrier [21].

Our experiments convincingly demonstrated that CDDP improves cognitive ability of VaD rats, positively modifies injured synaptic structures in VaD rats, and promotes PSD-95 mRNA expression in the cerebral structure crucially important for spatial memory (hippocampus).

Thus, our results showed that decreased expression of PSD-95 probably plays a key role in the pathogenesis of $\mathrm{VaD}$, and that CDDP exerts a protective influence on the synaptic plasticity in the hippocampus by improving expression of mRNA of this synaptic protein. Our study provides behavioral and biochemical evidences for a possibility of using CDDP therapy in VaD. However, the mechanism of how cerebral ischemia leads to decreased expression of PSD-95 remains unclear, and the mechanism of how CDDP affects the hippocampal neuronal mechanisms requires further studies. 
Acknowledgments. We wish to thank $\mathrm{H}$. Wu from the Animal Laboratory of the Fujian Institute of Traditional Chinese Medicine for raising the rats. This work was supported by the National Natural Science Foundation of China (grant No. 81001541) and the Natural Science Foundation of the Fujian Province (grant No. 2013J01331).

Rats were handled according to the National Guidelines of China for the Care and Use of Animals for Scientific Purposes. Protocols were approved by the Animal Care and Use Committee at the Fujian University of Traditional Chinese Medicine.

The authors, Yanzhen Zhu, Yanjun Zeng, Caigu He, Shu Jiang, Linying Zhou, Yumei Huang, Changhui Qiang, Yiyan Jiang, confirm that they have no conflicts of any kind related to the commercial or financial problems, relations with organizations or persons, which could in any way be associated with the investigation, and with the relationship of the co-authors of the article.

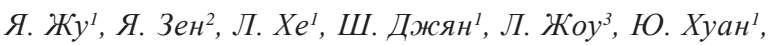
Ч. К'ян ${ }^{1}$, Йі. Джяян

\section{ВПЛИВ КАРДІОТОНІЧНОГО ЗАСОБУ «ПІЛЮЛІ ДАН- ШЕН» НА КОГНІТИВНІ ЗДАТНОСТІ ТА ЕКСПРЕСІЮ БІЛКА PSD-95 У ЩУРІВ 3 МОДЕЛЛЮ ВАСКУЛЯРНОЇ ДЕМЕНЦІЇ}

\footnotetext{
${ }^{1}$ Університет традиційної китайської медицини, Фуджянь (Китай).

${ }^{2}$ Інститут біомеханіки та медичної інформації Пекінського технологічного університету (Китай).

${ }^{3}$ Фунджянський медичний університет (Китай).

Р е 3 ю м е
}

Широко вживаний у Китаї патентований кардіотонічний засіб «складні пілюлі Даншен» (CDDP) почав також використовуватися для лікування васкулярної деменції (ВД). Ми досліджували можливі механізми дії цього засобу в даному аспекті. ВД моделювали у щурів, застосовуючи білатеральну перев'язку загальних сонних артерій. Когнітивні здатності експериментальних тварин оцінювали в тесті водного лабіринту Морріса. Ультраструктурні зміни синаптичних утворень у гіпокампі спостерігали, використовуючи трансмісійну електронну мікроскопію. Експресію мРНК білка PSD-95 у гіпокампі оцінювали із застосуванням методики гібридизації in situ. Останній показник (експресія мРНК) у щурів групи ВД був вірогідно нижчим, ніж у тварин контрольної групи та щурів із ВД, лікованих за допомогою CDDP. Середня затримка реакції уникання у тварин групи ВД істотно перевищувала відповідне значення в групі CDDP $(P<0.05)$. Стратегії уникання в останній групі були вірогідно кращими, ніж у групі ВД (збільшувалася пропорція лінійних маршрутів порівняно 3 «крайовими» та випадковими; $P<0.05)$. Зроблено висновок, що зниження експресії PSD-95 відіграє важливу роль у патогенезі ВД. Лікувальний ефект CDDP забезпечує покращення пам'яті та здатності до навчання у щурів з ВД; цей ефект опосередковується покращенням ультраструктурних показників синаптичних структур та збільшенням експресії мPHК білка PSD-95 у гіпокампі.

\section{REFERENCES}

1. G. C. Roman, "Vascular dementia revisited: diagnosis, pathogenesis, treatment, and prevention," Med. Clin. North Am., 86, No. 3, 477-499 (2002).

2. R. Hebert and C. Brayne, "Epidemiology of vascular dementia," Euroepidemiology, 14, No. 5, 240-257 (1995).

3. W. A. Rocca, A. Hofman, C. Brayne, et al., "The prevalence of vascular dementia in Europe: Facts and fragments from 19801990 studies; EURODEM-Rrev. Res. Group," Ann. Neurol., 30, No. 6, 817-824 (1991).

4. T. Erkinjuntti, G. Román, S. Gauthier, et al., "Emerging therapies for vascular dementia and vascular cognitive impairment," Stroke, 35, 1010-1017 (2004).

5. Y. L. Jia, F. Y. Huang, and S. K. Zhang, "Assessment of the quality of randomized controlled trials in treating coronary heart disease by chinese patent medicine," Zhongguo Zhong Xi Yi Jie He Za Zhi, 32, No. 4, 560-568 (2012).

6. J. C. Lee, J. H. Park, O. K. Park, et al., "Neuroprotective effects of tanshinone from Danshen extract in a mouse model of hypoxia-ischemia," Anat. Cell. Biol., 46, No. 3, 183-190 (2013).

7. X. Xu, Z. Li, Z. Yang, and T. Zhang, "Decreased synaptic plasticity associated with alteration of information flow in a rat model of vascular dementia," Neuroscience, 29, No. 206, 136-143( 2012).

8. M. Migaud, P. Charlesworth, M. Dempster, et al., "Enhanced long-term potentiation and impaired learning in mice with mutant postsynaptic density-95 protein," Nature, 396, No. 6710, 433-439 (1998).

9. Y. Zhu, Y. Zeng, X. Wang, and X. Ye, "Effect of electroacupuncture on the expression of MTOR and EIF4E in hippocampus of rats with vascular dementia," Neurol. Sci., 34, No. 7, 1093-1097 (2013).

10. D. L. Brody and D. M. Holtzman, "Morris water maze search strategy analysis in PDAPP mice before and after experimental traumatic brain injury," Exp. Neurol., 197, No. 2, 330-340 (2006).

11. J. Foucaud, J. G. Burns, and F. Mery, "Use of spatial information and search strategies in a water maze analog in Drosophila," PLoS One, 5, No. 12, 15231 (2010).

12. C. Janus, "Search strategies used by APP transgenic mice during navigation in the Morris water maze," Learn. Mem., 11, No. 3, 337-346 (2004).

13. D. Meyer, T. Bonhoeffer, and V. Scheuss, "Balance and stability of synaptic structures during synaptic plasticity," Neuron, 82, No. 2, 430-443 (2014).

14. J. Changeux and S. J. Edelstein, "Allosteric mechanisms in 
normal and pathological nicotinic acetylcholine receptors," Current Opin. Neurobiol., 11, 369-377 (2001).

15. H. Li and X. Xin, "Nitrogen dioxide $\left(\mathrm{NO}_{2}\right)$ pollution as a potential risk factor for developing vascular dementia and its synaptic mechanisms," Chemosphere, 92, No. 1, 52-58 (2013).

16. B. C. Yan, J. H. Park, J. H. Ahn, et al., "Postsynaptic density protein (PSD)-95 expression is markedly decreased in the hippocampal $C A 1$ region after perimental ischemia-reperfusion injury," J. Neurol. Sci., 330, Nos. 1/2, 111-116 (2013).

17. B. Wu, M. Liu, and S. Zhang, "Dan shen agents for acute ischemic stroke," Cochrane Database Syst. Rev., 18, No. 2, CD004295 (2007).

18. W. Wu, P. Kuang, and Z. Li, "Protective effect of radix Salviae Miltiorrhizae on apoptosis of neurons during focal cerebral ischemia and reperfusion," J. Tradit. Chin. Med., 17, No. 3, 220-225 (1997).
19. W. Wu, P. Kuang, and Z. Li, "Effect of radix Salvia Miltiorrhizae on the gene expression of nitric oxide synthase in ischemic rat brains," J. Tradit. Chin. Med., 18, No. 2, 128133 (1998).

20. J. Wang, J. Xu, and J. B. Zhong, "Effect of radix notoginseng saponins on platelet activating molecule expression and aggregation in patients with blood hyperviscosity syndrome," Zhongguo Zhong Xi Yi Jie He Za Zhi, 24, No. 4, 312-316 (2004).

21. W. J. Pei, X. F. Zhao, Z. M. Zhu, et al., "Study of the determination and pharmacokinetics of compound Danshen dripping pills in human serum by column switching liquid chromatography electrospray in trap mass spectrometry," $J$. Chromatogr. Ser. B, Analyt. Technol. Biomed. Life Sci., 809, No. 2, 237-242 (2004). 